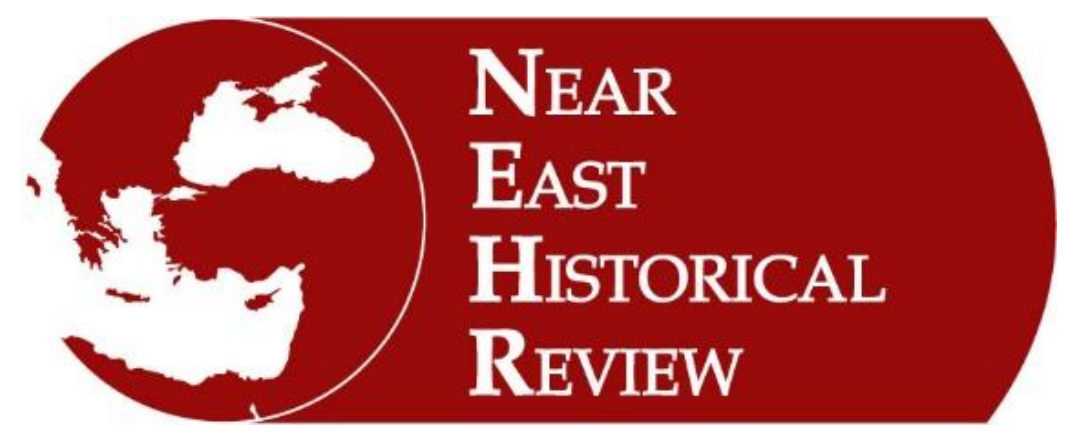

\title{
1893-1894 YILLARI ARASINDA SINOP'TA KOLERA SALGINI VE OSMANLI DEVLETI'NDE KOLERAYA KARŞI ALINAN TEDBİRLER
}

Cholera Epidemic in Sinop Between 1983-1894 and Measures Taken Against Cholera in The Ottoman Empire

\author{
Emrah Maral \\ Arş. Gör., Sinop Üniversitesi, Türkiye \\ e-mail: emrah.maral23@hotmail.com \\ ORCID ID: 0000-0002-2418-9739
}

Near East Historical Review
$11 / 1$, January / Ocak 2021
e-ISSN: 2717-6363 (Online)
www.nehrreview.com

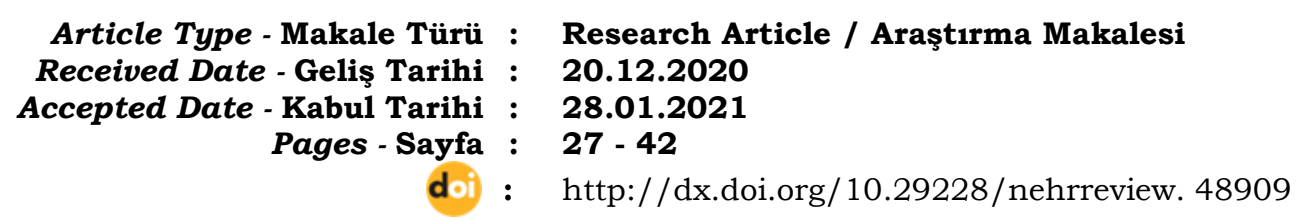

Citation - Attf : Emrah Maral, “1893-1894 Y1lları Arasında Sinop'ta Kolera Salgını Ve Osmanlı Devleti'nde Koleraya Karş1 Alınan Tedbirler", Near East Historical Review, 11/1, January, 2021, pp. 27 - 42 


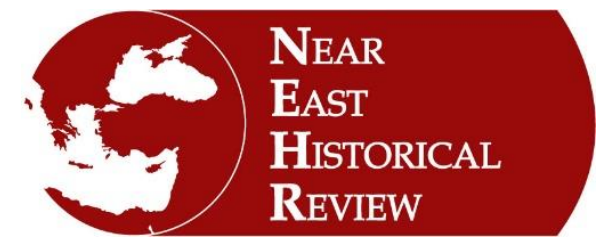

Near East Historical Review

11/1, January - Ocak 2021

$27-42$

Research Article - Araştırma Makalesi

\title{
1893-1894 YILLARI ARASINDA SINOP'TA KOLERA SALGINI VE OSMANLI DEVLETI'NDE KOLERAYA KARŞI ALINAN TEDBÍRLER
}

\author{
Cholera Epidemic in Sinop Between 1983-1894 and Measures Taken Against \\ Cholera in The Ottoman Empire
}

\author{
Emrah Maral \\ Arş. Gör., Sinop Üniversitesi, Türkiye \\ e-mail: emrah.maral23@hotmail.com \\ ORCID ID: 0000-0002-2418-9739
}

\section{Öz}

19. yüzyılın başlarında Hindistan'da ortaya çıkan ve belirli bir süre içerisinde yayılarak tüm dünyayı etkisi altına alan Kolera, Osmanlı Devleti'nde de sosyal ve ekonomik birçok soruna neden olmuştur. Kolera salgını nedeniyle şehirlerin nüfusu azalmakla kalmamıș, salgın yüzünden halk yerini yurdunu terk etmek zorunda kalmıştır. Bu hastalık hakkında halkın yeterli bilgisinin olmaması, fakirlik, yetişmiş doktor sayısının azlığı ve halkın kadercilik anlayışı, ciddi oranda nüfus kaybına neden olmaktaydı. Bu durum şehirlerde üretimin düşmesine ve hayat pahalılığına neden oluyordu. 1893 ve 1894 yıllarında kolera salgını İstanbul, İzmir, Diyarbakır, Erzurum, Trabzon gibi vilayet merkezlerinin yanında küçük çapta olmakla birlikte Sinop'ta da görülmeye başlamıştır. Sinop'un bir liman kenti olması ve tahaffuzhanenin burada kurulması nedeniyle koleraya karşı daha hassas bir konumda bulunmaktaydı. Kolera salgınının Osmanlı coğrafyasında da görülmesi üzerine Osmanlı Devleti, kolera ile mücadele etmek için birtakım önlemler almaya başlamıştır. Bu bağlamda, tahaffuzhanelerin kurulması, ülkeye giriş ve çıkışların yasaklanması, mülki idarelere temizlik konusunda talimatnameler gönderilmesi hep bu önlemler çerçevesinde gerçekleştirilen eylemlerdir. $\mathrm{Bu}$ çalışmamızda, koleranın tanımı ve özelliklerini, Osmanlı Devleti'nde hastalığın ortaya çıkması ve yayılmasını, Sinop'taki kolera vakalarını, bunlara karşı alınan önlemleri Başbakanlık Osmanlı Arşiv kaynakları ve tetkik eserlere dayanarak incelemeye çalıştık.

Anahtar Kelimeler: Osmanlı Devleti, Sinop, Kolera, Hastalık, Salgın.

\section{Abstract}

Cholera, which emerged in India at the beginning of the 19th century and spread over a certain period of time and affected the whole World, caused many socil and economic problems in the Ottoman Empire. Due to cholera epidemic, the population of the cities not only decreased, but because of epidemic, the people had to leave their homeland. Lack of public knowledge about this disease, philanthropy, low number of trained doctors, and the people's understanding of fatalism caused a serious loss of population. In 1893 and 1894, the cholera epidemic started to be seen in Sinop, albeit ona small scale, as well as in provincial centers such as İstanbul, İzmir, Diyarbakır, Erzurum and Trabzon. Since Sinop was a part city and the quarantine center was established here, it was in a more sensitive position against cholera. Thereupon, the Ottoman Empire started to take some measures to combat cholera. In this context, the establisment of quarantine centers, prohibition of entering and leaving the country, sending intructions to the civilian admunistrations to the on cleaning are all actions taken within the framework of these measures. In this study, we tried to examine the definition and characteristics of cholere, the emergence and spread of the disease in the ottoman Empire, the cases of cholera in sinop, the precautions taken against them, the Prime Ministry Ottoman Archive sources and some studies.

Keywords: Otoman Empire, Sinop, Cholera, Disease, Epidemic. 


\section{Giriş}

İnsanlık savaşlar ve tabi afetlerle devamlı bir mücadele içerisinde olmuştur. Bunların yanında insanlığı derinden sarsan ve büyük ölümlere neden olan bir diğer olay da salgın hastalıklardır. İnsanlık tarihi kadar eski olan salgın hastalıklar, göç, ticaret, savaş gibi nedenlerle farklı coğrafyalara yayılarak çok sayıda insanın toplu halde ölmesine neden olmuştur. Tarihi süreç içesinde salgın hastalıkların adı, yeri ve zamanı değişmiş olsa da insanlar üzerindeki yıkıcı etkisi günümüze kadar devam etmiştir. Geçmiş dönemlerin en yıkıcı salgın hastalıkları arasında özellikle veba, sıtma, çiçek, kolera, frengi gibi hastalıklar başta gelmiştir.

Anadolu'da M.Ö. 2 binli ${ }^{1}$ yıllardan beri süre gelen veba hastalı̆̆ , Bizans ve Anadolu Selçukluları devrinde de devam etmiştir. ${ }^{2}$ Yakınçağ' $1 n$ ortalarına kadar etkisini dönem dönem sürdürmekle beraber, Osmanlı Devleti'ni de yaklaşık olarak her on yılda bir yoklayıp çok canlar almıştır. ${ }^{3}$ Ticaretin yoğun olması nedeniyle veba salgınları İstanbul'da da görülmüştür. İstanbul'un ardından vebanın en fazla görüldüğü ve kayıplara neden olduğu merkez İzmir olmuştur. Bunun nedeni ise bu şehirlerin diğer bölgelerle yoğun temas içerisinde olmasıdır. ${ }^{4}$

Yakınçağın başlarında vebanın yanında bir de kolera salgını ortaya çıkmıştır. Hindistan'da endemik ${ }^{5}$ bir hastalık olan kolera dünyaya 1817 yılında yayılmaya başlamıştır. ${ }^{6} 19$. yüzyılda koleraya karşı Avrupa'da çeşitli tedbirler alınıp, birtakım tedavi yöntemleri uygulanmıştır. Osmanlı Devleti ise koleraya karşı eski usul tedavilere devam etmiş veya kadere razı olarak bu konuda yeterli tedbirleri almamıştır. ${ }^{7}$ Bunun nedenleri arasında fakirlik ve cehalet başta yer almıştır. Zira koleranın en fazla tahribatı fakirler üzerinde yaptığı tespit edilmiştir. ${ }^{8}$ Çünkü kolera bir toplumun sosyal ve ekonomik durumu ölçüsünde etkisini göstermektedir. Cahil kesim arasında hastalığa inanmayanların oranı bir hayli fazla olmuştur. Bu hastalığın ciddiyetine inanmayan kesimler, kolerayı doktorların çok fazla para almak maksadıyla ortaya çıkardıklarını ve bu durumu da çoğu hastaların doktorlar tarafından bilerek zehirlendiği dedikodusunu yaymışlardır. ${ }^{9}$ Ayrıca koleranın fakirlerin hak arama isteklerini bastırmak için, ortaya atılmış bir yalan olduğu da halk arasındaki rivayetler arasındaydı. ${ }^{10}$ Kolerada salgının çok olmasının bir diğer nedeni de ecel ve kader meselesidir. Bu mesele maalesef dini bir kisve altında gösterildiği için, insanlar "zaten ecelden kaçış olmaz, bu kadar tedbire ne gerek var" düşüncesiyle her türlü tedbire karşı çıkmışlardır. ${ }^{11}$ Bu nedenle en büyük yıkım kadercilik nedeniyle herhangi bir tedbir

\footnotetext{
${ }^{1}$ M.Ö 2. Binyılın ikinci çeyreğinden itibaren Orta Anadolu'ya hâkim olup güçlü bir siyasi birlik kurmuş olan Hititler veba yüzünden çok kayıplar vermiştir. Mısırla yapılan antlaşma gereği Hitit Prensi Mısır'a gitmek üzere yola çıkmışken bir şekilde düşmanlar tarafından yolda öldürülmüş̧ür. Bunun üzerine Hitit kralı Şuppiluliuma oğlunun intikamını almak için Mısır üzerine sefer düzenlemiştir. Yapılan sefer neticesinde ele geçirilen pek çok esir Hatti ülkesine getirilmiştir. Lakin ele geçirilen bu esirlerde vebanın ortaya çıkmasıyla beraber esirler yavaş yavaş ölmeye başlamış ve veba salgını Hatti ülkesinde 20 yıl kadar devam etmiştir. Ülke nüfusunun önemli bir kısmı bu salgında ölmüştür. Öyle ki Şuppiluliuma Gaşka seferine çıkarken veba salgınının kurbanı olmuştur. (Ekrem Memiş, Eskiçağ Türkiye Tarihi, 15. Bask1, Bursa 2020, s.116).

${ }^{2}$ Orhan Kılıç, Eskiçağdan Yakınçağa Genel Hatlarıyla Dünyada ve Osmanlı Devleti’nde Salgın Hastalıklar, Elazığ 2014, s.23.

${ }^{3}$ Daniel Panzac, Osmanlı İmparatorluğunda Veba, Çev. Serap Yılmaz, İstanbul 1997, s. 36.

${ }^{4}$ Antonie Olivier, Türkiye Seyahatnamesi(1790 Yıllarında Türkiye ve İstanbul), C.1, Çev. Oğuz Gökmen, Ankara 1977, s.120.

${ }^{5}$ Belirli bir coğrafya, bölge veya nüfus içerisinde, her zaman var olan bir hastalığı tanımlamak için kullanılan bir terimdir. ( Miquel Porta, A Dictıonary of Epidemiology, Fifth Edition, Oxford University Press 2008, s. 78).

${ }^{6}$ İsmail Yaşayanlar, “Bir Kent, İki Salgın: Antep’te 1848 ve 1890 Kolera Epidemileri”, Uluslararası Gaziantep Tarihi Sempozyumu Milli Mücadele Döneminde Gaziantep Bildiri Metinleri Kitabı, 2017, s.271.

${ }^{7}$ Edhem Necdet, Kolera Tabibi, İstanbul 1326, s. 3.

${ }^{8}$ Edhem Necdet, a.g.e., s. 5.

${ }^{9}$ Edhem Necdet, a.g.e., s. 5.; Süleyman Numan, Kolera, Kostantiniyye, Matbaa-i Ebuzziya, Sene 1326, s.50.

${ }^{10}$ Mesut Ayar, Osmanlı Devletinde Kolera İstanbul Örneği ( 1892-1895) İstanbul 2007, s.221.

${ }^{11}$ Edhem Necdet. a.g.e., s. 6.
} 
almayan Müslüman ahali arasında olmaktaydı. ${ }^{12}$ Müslümanların davranışlarında din belirleyici rol oynadığı için, hastalığı alın yazısı görüp boyun eğmişlerdir. ${ }^{13} 1812$ yılında İstanbul'da kara veba kol gezerken ve günde 2000'e yakın insan ölürken, çaresiz ve korku içinde kalan insanlar da dualarla vebadan kurtulacaklarını sanmışlardır. Öyle ki, camilerden Duhan Suresinin ${ }^{14}$ okunması için, ilgili yerlere fermanlar gönderilmiştir. ${ }^{15} \mathrm{Bu}$ durum kolera salgınında da devam etmiş ve padişahın emriyle hem Müslüman ve hem de diğer din mensuplarının salgından kurtulmak için, Tanrıya yakarmaları istenmiş bütün camii, mescit ve tekkelerde namaz esnasında Ahkaf Suresinin ${ }^{16}$ okunması, namaz sonrası tevbe-istiğfar edilmesi için padişah tarafından emirler verilmiştir. ${ }^{17}$ Günümüze geldiğimiz vakit Dünya genelinde hızlı bir şekilde yayılan COVID-19 salgını, hastalı̆̆ın yayılma hızı ve ciddiyeti nedeniyle Dünya Sağlık Örgütü tarafından 12 Mart 2020'de COVID-19'u pandemik bir hastalık olarak ilan etmiştir. ${ }^{18} 13$ Mart 2020 tarihinde Türkiye Diyanet İşleri Başkanlığı hijyen konusunda bir hutbe yayınlamış, Din İşleri Yüksek Kurulu fetvasında; risk grubundaki Müslümanların Cuma namazı yerine evde öğle namazını k1labileceklerini, virüslü hastaların toplu yerlere gitmelerinin caiz olmadığ 1 ve karantina bölgelerinde Cuma namazının farz olmadığını bildirmiştir. Aynı gün müftülüklere gönderilen bir genelgeyle de toplu kullanım alanlarının kullanımı ve Kur'an kurslarının tatil edilmesi ve umre ziyaretlerinin durdurulduğu bildirilmiştir. ${ }^{19}$

Koleranın halk üzerindeki etkilerinden biri de, genç kuşakların kaybıdır. Koleraya en çok 20-30 yaş, en az da 1-15 yaş grubu yakalanmıştır. ${ }^{20}$ Koleranın nüfus kaybına neden olmasının yanında üretim ve ticari hayatı da sekteye uğrattığı değişmeyen bir gerçektir. Nitekim salgınlar esnasında karantina ve kordonların uygulanması, halkın evine kapanıp çalışamaması ticaretin durmasına ve hayat pahalılığına yol açmıştır. ${ }^{21}$ Üretimin olmaması, işlere durgunluk getirmiştir. $\mathrm{Bu}$ nedenle de insanlar bulunduğu yeri terk etmek zorunda kalmışlardır. Ayrıca salgınlar nedeniyle yaşanan ölümler iş gücünün azalmasına da neden oluyordu. Bu ise arz talep dengesinin bozulmasına, kıtlığa ve kara borsacılığa neden olmuştur. ${ }^{22}$ Kitlık dönemlerinde insanların yetersiz beslenmesi vücut direncini düşürüp, hastalıklara karşı savunmasız bir duruma gelmesine neden olmuştur. ${ }^{23}$ İzmit'te kolera vakaları artınca halk civar köylere ve kasabalara sı̆̆ınmaya başlamıştır. Burada bulunan Karantina hekimi ve görevli memurlar da kenti terk ederek

${ }^{12}$ Cyrus Hamlin, Türkiye'deki Misyonerlik Faaliyetleri, Çev. Arzu Taşcan, İstanbul 2015, s. 278.

${ }^{13}$ Daniel Panzac, Osmanlı İmparatorluğunda Veba (1700-1850), Çev. Serap Yılmaz, İstanbul 1997, s. 150. ; A. Olivier, a.g.e., s.117.

${ }^{14}$ Mekke Döneminde inmiştir. 59. Ayettir. Sûre adını onuncu ayette geçen "Duhan" kelimesinden almıştır. Duhan, duman demektir. Dûhan suresinin başlıca konusu, Kur'an-1 Kerim'in indirilişi, müşriklerin ona karşı tutumu, Firavun ve kavminin başına gelen azaplar, Kureyş'in Hz. Peygamberi yalanlaması, iyilerin ve kötülerin karşılaşacakları akıbet konu edilmiştir. Sûrenin mealinde, Fakat onlar, şüphe içinde eğlenip duruyorlar. Göğün açık bir duman getireceği günü bekle. O duman insanları bürür. Bu, elem dolu bir azaptır. İnsanlar, "Rabbimiz! Bu azabı bizden kaldır, çünkü biz artık inanıyoruz” derler. (Diyanet İşleri Başkanlığı, Kur'an-ı Kerim Meali, 14. Baskı, Ankara, 2012, s. 548.)

${ }^{15}$ Cabi Ömer Efendi, Cabi Tarihi, C. II. Hazırlayan. M. Ali Beyhan, Ankara 2003, s.898.

${ }^{16}$ Ahkaf Sûresi Mekke döneminde inmiştir. 35. Ayettir. Sûre, adını 21. Ayette geçen "Ahkaf” kelimesinden almıştır. Sûrenin mealinde, İnkâr edenler ateşe sunuldukları gün, onlara şöyle denir: "Dünyadaki hayatınızda güzelliklerinizi bitirdiniz, onların zevkini sürdünüz. Bugün ise yeryüzünde haksız yere büyüklük taslamanızdan ve yoldan çıkmanızdan dolayı, alçaltıı bir azapla cezalandırılacaksınız”. (Diyanet İşleri Başkanlığı, Kur'an-ı Kerim Meali, 14. Bask1, Ankara 2012, s.558.)

${ }^{17}$ M. Ayar, a.g.e., s.233.

18 İbrahim Arslan- Soner Karagül, "Küresel Bir Tehdir ( COVID19 Salgını) ve Değişime Yolculuk", Üsküdar Üniversitesi Sosyal Bilimler Dergisi, S. 10, İstanbul 2020, s. 2.

${ }^{19}$ Muhittin Imıl, "Kutsal Dünyanın Virüsle İmtihanı: Post-Pandemik Dönem ve Din”, Dini Araştırmalar Dergisi, C.23, S. 57, Ankara 2020, s.78.

${ }^{20}$ Nuran Y1ldırım, “1893 İstanbul Kolera Salgını İstatistikleri”, Tarih ve Toplum Dergisi, S. 150, 1996, s.53.

${ }^{21}$ M. Ayar, a.g.e., s.243.

22 Orhan Kılıç, "16-18. Yüzyıllarda Balkan Şehirlerinde Yaşanan Veba Salgınları ve Sosyo-Ekonomik Etkileri”, Osmanl Dönemi Balkan Şehirleri, C. 3, 2017, s.1202.

${ }^{23}$ S. Oğuz Baytimur-Özcan Tatar, "Osmanlı Devleti'nde Çekirge İstilaları ve Sosyo-Ekonomik Hayata Etkileri (17891839)”, Avrasya Uluslararası Araştırmalar Dergisi, C. 8, S. 23, 2020, s. 341. 
karantinahaneyi yakmışlardır. ${ }^{24}$ Tuna taraflarında kolera baş gösterince burada yaşayan Osmanlı vatandaşları geçimlerini sağlayamaz hale düşmüşler ve bu yüzden farklı ülkelere göç etmeye başlamışlardır. Bunlardan bazıları Romanya'nın hastalıklı olmayan yerlerine, bazıları da Bulgaristan, Sırbistan, Macaristan gibi ülkelere göç etmişlerdir. Gücü yetmeyen fakir insanlar ise sıkıntı içinde yardım elinin uzatılmasını beklemişlerdir. ${ }^{25}$ Veba, kolera, sıtma, kızamık, çiçek gibi hastalıkların önüne 20. asırda geçilmiş olsa da, Osmanlı Devleti'nde nüfusa büyük darbe vurmaya devam etmiştir. ${ }^{26}$ Kolera, Osmanlı Devleti'ni 1822 'den itibaren birçok defa istila etmiş ve yalnız İstanbul'da kayıp sayısı 37 bin kişi olmuştur. Bu durum İstanbul için geçerlidir ve Osmanlı'nın nüfusu bu tarihte otuz milyon civarındadır. Anadolu veya diğer yerler de hesaba katılırsa kaybın boyutunun korkutucu boyutu daha iyi anlaş1labilir. ${ }^{27}$

Koleranın hızlı bir şekilde bulaşmasında iletişim araçlarının artması ve teknolojik yeniliklerle mesafelerin kısalması da etken olmuştur. Buhar gücünün ve elektriğin kullanılması, uzak mesafeleri yakın etmiş bu nedenle de koleranın yayılma hızı artmıştır.

\section{Kolera Tarihine Bakış ve Osmanlı Devleti'nde Hastalığın Yayılma Süreci}

Kolera, hafif bir karın ağrısı, şiddetli ishal ile kısa süre içerisinde vücudun büyük miktarda su kaybetmesine neden olan bir enfeksiyon hastalığıdır. Dışkı ilk etapta normal şekilde olur fakat bir gün içinde sulanıp rengi açılmaya başlar. ${ }^{28}$ Günde 10-20 kere sancılı bir şekilde zuhur eder. Cilt kup kuru, idrarı pek azdır, ses kısılır, gözler çöker, renk solar ve hasta soğumaya başlar. Gaita pirinç suyu şeklini alır. Vücut 1sısı 36 derece ve daha aşağıya düşer nabzı küçülür. ${ }^{29}$ Aniden başlayan kolerada ise şiddetli kusmadan sonra ishal başlar ardından derin bir halsizlik görülür, şiddetli kusma nedeniyle hastanın yeme içmesi olanaksız olur. Kusma ve ishalin şiddeti çok fazla olduğu için hastanın su kaybından dolayı dokuları kurumaya başlar. ${ }^{30}$

Kolera adının ilk olarak Hipokrat tarafından kullanılmış olduğu söylenmesine rağmen, tarif ettiği bu hastalığın kolera olup olmadığı tam olarak bilinmemektedir. İlk olarak 7. yüzyılda Susruta, klinik görüşlerini ve özelliklerini yayınlamıştır. ${ }^{31}$ Kolera mikrobu, Hindistan'da Ganj nehrinin deltalarında özellikle Kalküta'da ortaya çıkmıştır. ${ }^{32}$ Hindistan'da yaşanan kolera salgınları ile ilgili ilk bilgiden Portekizli kâşif Gaspar Correia Lendas da İndia adlı eserinde bahsetmiştir. ${ }^{33}$ Kolera burada hemen her vakit görülür yalnız en fazla sıcak ve yağmuru az olan Nisan ayında, en az da sıcak ve rutubetli olan Ağustos ayında görülür. ${ }^{34}$ Fakat salgının yayılma hızı, ulaşım teknikleri yoğun bir şekilde kullanılmadığı için sınırlı ve düşük seviyede kalıyordu. 20. asırla beraber elektrik ve buharlı araçların kullanılmasıyla mesafeler çok kısalmış ve başka toplumlarla temas kurmak fazlasıyla kolaylaşmıştır. Bu asırda farklı toplumlarda nakliye araçları, vapur ve tren yolculuklariyla kolera az zamanda çok büyük mesafeler kat edip kara üzerinde birçok yerlere ulaşmıştır. ${ }^{35}$ Ayrıca Hindistan'1 sömürgesi haline getiren İngiltere, hastalığın yayılmasında bir diğer etkendir. Şöyle ki, Hindistan'da savaşan İngiltere, askerleri aracılığıyla

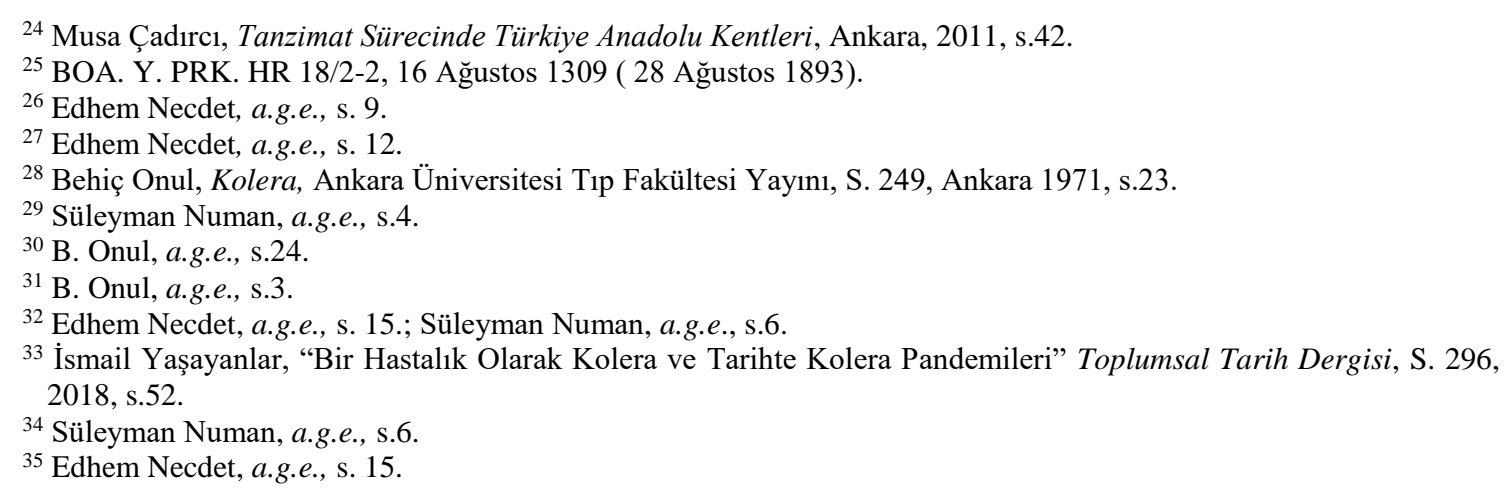

Near East Historical Review www.nehrreview.com 
virüsü kapıp Nepal, Afganistan, Seylan, Endonezya, Çin ve Japonya gibi ülkelere taşırken, yerlerinden sürdükleri Hintliler de hastalığı başka yerlere taşımışlardır. ${ }^{36}$

Kolera mikrobu büyük Alman tabiplerinden Robert Koch tarafindan keşfedilmiştir. Koch kolerayı araştırmak için Alman hükümeti tarafindan Hindistan'a gönderilmiştir. Koch önce Mısır'da kolerayı değerlendirmiş ve sonunda mikrobu keşfetmek için Hindistan'a gitmiştir. Burada birçok araştırmadan sonra Koch gaitada kolera mikrobu olan koma basili bulunduğunu ispatlamıştır. Hastaların yarısında yapılan tetkiklerle bir iki dakika zarfında sonuç alarak, Asya kolerasının teşhisini yapmanın mümkün olduğunu göstermiştir. ${ }^{37}$ Koleranın diğer ülkelerde de incelenmesi sonucu bu mikrobun ülkeden ülkeye değiştiği görülmüştür. Fakat bu mikrop bütün hastalıkların sebebidir. ${ }^{38}$ Koch'un mikrobu bulup bilim âleminde ispatlamasından sonra bütün âlem Koch'un "asil virgül" adını verdiği mikroptan, koleranın meydana geldiğini kabul etmiştir. ${ }^{39}$

Osmanlı Devleti'nde Bakteriyoloji laboratuvarının 13 Eylül 1910'da çıkardığı raporla, koleranın ülkemizdeki resmi teşhisi kabul ve ilan edilmiştir. Bu raporda, "kolera ancak hastaların gaitasında virgül basilinin bulunmasıyla teşhis edilir" ${ }^{\prime 40}$ ibaresi yer almıştır.

Koleranın bulaşma şekli başlıca iki yoldan olmuştur. Kirli suların içilmesi ve hastalarla doğrudan temas şeklindedir. ${ }^{41}$ İçeceklerden en önemlisi sudur. Mikrobun kâşifi denilecek biri olan Koch öncelikle koleranın sulardan bulaştığını ispatlamıştır. Fakat akan sularda kolera mikrobu olmuyordu. Denizlerde ise kolera şüphesiz ki sandallar ve vapurların hareketiyle bir yerden bir yere gidiyordu. ${ }^{42}$ Akan suların aksine, gemilerin yüzdügü nehirlerde kolera mikrobu görülmekteydi. Şöyle ki, Seyri sefer esnasında yüzen gemilerin yolcu veya sairleri hacetlerini nehre atarlard. Bunlar "koleralı" bir yerden hareket etmişlerse ve aralarında hasta veya mikrobu taşıyan biri varsa gaitasında bulunan kolera mikropları nehrin suyuna geçer ve arkadan gelen diğer bir kayık veya gemi taifeleri bu sudan içerse mikroplar direkt olarak yeni bir kişiye bulaşmış oluyordu. Tabii olarak vapur veya tekne limana yanaşınca, teknede hastalanan kişi mikrobu limandakilere bulaştırarak hastalığın yayılmasına neden olmuştur. ${ }^{43}$

Hindistan'a özgü bir hastalık olan kolera, ticaret yolları, hacılar ve İngilizler nedeniyle dünyaya yayılarak çok fazla kişinin ölümüne neden olmuştur. 1816 yılında Bengal'den yayılmaya başlayıp bütün Hindistan'ı etkisi altına aldıktan sonra, ilk defa 1822 yılında Basra Körfezi'nden, Bağdat yoluyla Anadolu ve Akdeniz sahillerine ulaşarak Osmanlı Devleti'nde de yayılmıştır. 1826 yılındaki ikinci küresel salgında 1829 yılında Rusya'y1, 1831'de Çin, Almanya, İngiltere, Osmanlı Devleti ve Afrika'yı etkisi altına alan salgın 1832'de Amerika ve Kanada'ya ulaşmış ve 25 milyon kişinin ölümüne neden olmuştur. ${ }^{44}$ Çünkü o dönemde kolera yalnız hastalarla, koleradan ölenlerden yayılır sanılıyordu. Hakikatte ise araştırmalar neticesinde anlaşılmıştır ki kolera, mikrobu taşıyan fakat hastalığa yakalanmayanlar tarafından en fazla yayılmıştır. Mikroplar bu gibi şahısların bağırsaklarında iki hafta kadar yaşayabilirlerdi. ${ }^{45}$ Eskilerin zannettiği gibi mikropların bağırsaklardaki gelişimi 2-4 gün değil de 1-12 gün arasındadır. Isşte bu nedenle tahaffuzhanelerde yolcuların beş gün bekletilmesi, koleranın yayılmasını engelleyememiştir.

\footnotetext{
${ }^{36}$ M. Ayar, a.g.e., s. 6

${ }^{37}$ Süleyman Numan, a.g.e., s. 108.

${ }^{38}$ Edhem Necdet, a.g.e., s. 36.

${ }^{39}$ Edhem Necdet, a.g.e., s. 37.

${ }^{40}$ Süleyman Numan, a.g.e., s.103.

${ }^{41}$ Erol Karc1, “Osmanlı Devleti'nde Bakteriyoloji Öğretiminin Öncüsü Doktor Hamdi Aziz Paşa ve 1902-1904 Irak Kolerasına Dair Tespitler”, Selçuk Üniversitesi Türkiyat Araştırmaları Dergisi, S.49, Konya 2020, s. 405.

${ }^{42}$ Edhem Necdet, a.g.e., s. 27.

${ }^{43}$ Süleyman Numan, a.g.e., s.41.

${ }^{44}$ Fatma Yıldız, 19. Yüzyıl'da Anadolu'da Salgın Hastalıklar (Veba, Kolera, Çiçek, Sitma) ve Salgın Hastalıklarla Mücadele Yöntemleri, (Basılmamış Yüksek Lisans Tezi), Pamukkale Üniversitesi, Sosyal Bilimler Enstitüsü, Denizli 2014, s.19.

${ }^{45}$ Edhem Necdet, a.g.e., s. 17.
} 
Yalnız bu beş gün zarfinda koleraya yakalanacaklardan korunmak mümkün oluyor, bu süre içinde hastalığa yakalanmayanlar ve mikrobu taşıyanlar, karantinada bekledikten sonra artık hiçbir kayıtlı sıhhiyeye lüzum görmüyorlar ve gittikleri yerlerde mikropları bulaştırarak birçok salgın ve hastalık yuvalarına sebep oluyorlard.$^{46}$

Sürekli yer değiştiren ve hareket halinde olan insanlar da koleranın yayılmasına sebep olmuşlardır. Hastalığın yayılmasına etken olan bir grup da çingenelerdi. Çingeneler, her yıl yaz mevsiminin başlamasıyla birlikte 5-10 çadırlık gruplar halinde, kendileri yaya olmak üzere, eşya ve çocuklarını da beygir ve merkeplere yüklemek suretiyle, dağ köylerine göç eder, bu köylerin etrafındaki arazilere konarak çadırlarını kurarlardı. Temizliğe riayet etmeden yaşamlarını sürdürdükleri için, kolera ve tifo gibi bulaşıcı hastalıkların baş taşıyıcısı olarak bilinmişlerdir. ${ }^{47}$

Tarihin her döneminde çok sayıda insanın ölümüne yol açan salgın hastalıklara karşı başlangıçta basit yöntemlerle yapılan mücadelenin 19. yüzyılda modern bir şekle bürünmesiyle karantina teşkilatının temelleri atılmıştır. Özellikle koleranın yarattığı endişe devletleri bu amansız düşmana karşı işbirliğine sevk etmiş ve sağlık teşkilatlarının kuruluşunu hızlandırmıştır. Nitekim İngiltere'de 1832 yılında görülen kolera salgını yerel sağlık teşkilatının kuruluşunu hızlandırmıştır. Osmanlı Devleti'nde de Sıhhiye Teşkilatının temellerinin atılması salgın hastalıkların ortaya çıkarmış olduğu zorunlulukla paralellik arz etmiştir. Osmanlı Devleti, 19. yüzyılın ilk yarısında toprakları dışında ortaya çıkan salgın hastalıklara karşı tedbir olarak karantina uygulamış ve karantina meclisini kurmuştur. Karantinanın Osmanlı Devleti tarafından tedbir amacıyla ilk uygulanışı Rusya'daki kolera salgını nedeniyle olmuş ve bu ülkeden gelen ticaret gemilerine uygulanmıştır. 1831'de İstanbul Boğazı'nda uygulanan karantina ise Osmanlı Devleti'nde uygulanan ilk ciddi karantina uygulaması olmuştur ${ }^{48}$.

Osmanlı Devleti'nde Tanzimat Dönemi içerisinde alınan sıkı tedbirlere rağmen 1841, 1847, 1849 ve 1869 yıllarında veba, $1847-1848$ 'de kolera salgınları olmuştur. ${ }^{49}$ Osmanlı Devleti'nde ilk defa 1822 yılında görülen kolera, 1831'de de Odesa'dan gelen bir gemi aracılığıyla İstanbul'da ilk defa yayılmaya başlamıştır. İlk etapta sebebi bilinmeyen bu hastalığa karşı Hekimbaşı Behçet Efendi tarafından kolera risalesi adlı bir çalışma hazırlanıp, ilgili makamlara dağıtılmıştır. ${ }^{50}$ İstanbul'u etkisi altına alan bu ilk salgında günlük insan kaybı 12 den 200 kadar yükselmiş ve 6 bin kişinin ölümüne neden olmuştur. Bu nedenle halk arasında büyük bir korku ve endişe meydana gelmiştir. ${ }^{51}$

İkinci kolera salgını 1841-1842 de başlamış, evvela Acemistan'dan Arabistan'a geçmiş ve oradan İngiltere ve Fransa'ya bulaşıp, şiddetli bir şekilde devam etmiştir. Salgın Anadolu'ya Kafkasya üzerinden gelmiş, önce Erzurum'a oradan Trabzon yoluyla İstanbul'a geçmiştir. ${ }^{52}$ İstanbul'a 1847 tarihinde ulaşmış olan kolera hakkında en doğru bilgiyi Fransız delegesi Fauvel, hükümetine verdiği raporda detaylı bir şekilde anlatmıştır. ${ }^{53}$ Trabzon'dan İstanbul'a gelen Avusturyalı bir şirkete ait olan Lloyd isimli bir gemide üç kişinin koleradan ölmesi üzerine,

\footnotetext{
${ }^{46}$ Edhem Necdet, a.g.e., s. 17.

47 İsmail Altınöz, "Osmanlı Toplum Yapısı İçinde Çingeneler, Türkler Ansiklopedisi, Editör: Hasan Celal Güzel, Salim Koca, Yeni Türkiye Yayınları, Cilt 10, Ankara 2002, s.778.

${ }^{48}$ Necati Çavdar-Erol Karcı, "XIX. Yüzyıl Osmanlı Sağlık Teşkilatlanmasına Dair Bibliyografik Bir Deneme”, Turkish Studies, Volume 9/4, Spring 2014, s. 258.

${ }^{49}$ Mehmet Yavuz Erler, "XIX. Yüzyıldaki Bazı Doğal Afetler ve Osmanlı Yönetimi” Türkler Ansiklopedisi, Editör: Hasan Celal Güzel, Salim Koca, Yeni Türkiye Yayınları, Cilt 13, Ankara 2002, S.1387.

50 Özgür Yılmaz, "1847-1848 Kolera Salgını ve Osmanlı Coğrafyasındaki Etkileri”, Avrasya İncelemeleri Dergisi, VI/1, 2017, s. 42.

${ }^{51}$ Edhem Necdet, a.g.e., s. 21.

${ }^{52}$ Edhem Necdet, a.g.e., s. 21.

${ }^{53}$ Süleyman Numan, a.g.e., s.12.
} 
hastalık İstanbul'da yayılmaya başlamıştır. ${ }^{54}$ Bu ikinci kolera salgınında İstanbul' da 9 bin kolera vakası görülmüş ve 4 bin civarında da ölüm gerçekleşmiştir. ${ }^{55}$

İstanbul'daki üçüncü kolera salgını ise 1854'te meydana gelmiştir. Hastalık Fransız askerleri tarafından İstanbul'a taşınmıştır. Kolera, Marsilya'ya yayılmış bir vaziyetteydi. Kırım Savaşı nedeniyle Marsilya ve Kırım'dan gelen Fransız askerleri vasıtasıyla önce Gelibolu'ya ve yine aynı asker ve gemilerle İstanbul'a hastalık taşınmıştır. Mesajeri vapurlarından "Tabur" vapuru vasıtasıyla Gelibolu'ya ve yine aynı vapur hasta bakıcılarından biri Maltepe Askeri Hastanesine gelerek, hastalığ ilk başta bu hastaneden olmak üzere İstanbul'a yaymıştır ve bu kolera salgınında, doğru istatistikler olmamakla beraber, 3200-3500 kadar kişi vefat etmiştir . ${ }^{56}$

Dördüncü kolera salgını İstanbul'da Haziran 1865 tarihinde başlamıştır. Bu salgında kolera İstanbul'un her tarafını sarmış ve yaz sonuna doğru günde binden fazla ölüm meydana gelmiştir. Ölü sayısı 30 bin kişiyi bulduğundan bu salgın toplumsal hafızada büyük salgın diye yer etmiştir. ${ }^{57} \mathrm{Bu}$ salgın da Misır yoluyla ülkeye bulaşmıştır. Osman Paşa, Muhbir-i Sürur Fırkateyni ile Mısır'dan gelirken, vapurda koleradan vefat olduğu ve hastalık bulaşanlar olduğu halde, Osman Paşa ve Fırkateyn kumandanının baskısıyla vapur tabibi hastalığı saklamıştır. Ertesi günü Temmuz başında vapur taifesinden hasta olanlar bahriye hastanesine nakledilirken, kolera oldukları ortaya çıkmıştır. Bundan dolayı kolera, tersane sivil amelesi vasıtasıyla her tarafa yayılmıştır. ${ }^{58}$ Bu salgın İstanbul dışında Yafa, Nablus, Hayfa, Sayda, Beyrut, Şam, Hama, Humus, Halep, Adana ve Tarsus gibi güney şehirlerinde 40 binden fazla insanın hayatını kaybetmesine neden olmuştur. ${ }^{59}$ Avrupa, Osmanlı Devleti'nin iç işlerine karışmak bahanesiyle Hicaz'daki kolera nedeniyle Osmanlı Devleti'ni eleştirmekteydi. Onlara göre kolera Osmanlı coğrafyasından Avrupa'ya taşınmaktaydı. 1865 yılındaki kolera vakası Osmanlı topraklarında ilk olarak Hicaz'da etkili olmuştu. Bu yıl Hacc-1 Ekber olması nedeniyle 150 bin civarı hacı Hicaz'da toplanmış, kolera nedeniyle ölü sayısı 15 bin'i bulmuştur. ${ }^{60}$ Osmanlı Devleti, Rusya ve Hindistan'dan Hicaz'a giden hacılarda ciddi oranda kolera vakaları görünce, 1865 yılında Hicaz'a hususi bir sıhhiye heyeti göndermiştir. Bu heyet hastalık için pek çok koruma tedbirleri almasının yanında çevre temizliği ve su tedariki gibi beledi işlerden de sorumlu tutulmuştur. ${ }^{61}$ Evvela yüzlerce hacı bir yerde toplu halde bulunurken, özel evler tedarik edilmiş ve bu evlere onar onar hacılar yerleştirilmiştir. Burada temizliğe çok dikkat edilerek, koruma tedbirlerine çok büyük itinalar gösterilmiştir. ${ }^{62} 1865$ salgınından sonra Fransa, uluslararası bir konferans yapılması çağrısında bulunmuştur. Konferansın amac1, hastalığın başlıca nedenleri, karakteristiği ve başlangıç noktasının tespitini belirlemedir. Yapılan çağrılar olumlu karşılık bulmuş ve konferans 1866 yılında İstanbul'da yapılmıştır. Burada kolera salgınının Hicaz'dan dönüş yapan hacılar vasıtasıyla başka bölgelere yayıldığı konusunda görüş birliğine varılmıştır. ${ }^{63}$ Sihhiye komisyonu tarafından ise Osmanlı Devleti'nde altı tahaffuzhanenin ${ }^{64}$ varlığ 1 zaruri görülmüştür. Bunlar;

54 Ö. Yılmaz, a.g.m., s. 42.

${ }^{55}$ Edhem Necdet, a.g.e., s. 21.

${ }^{56}$ Süleyman Numan, a.g.e., s.15.

${ }^{57}$ Nuran Yıldırım, "Kolera Salgınlarında Şehir Hijyeni: İstanbul'da Kanalizasyonlar, Su Şebekesi ve Tedbirhaneler”, Mimarlık ve Tasarım Kültürü Dergisi, S. 342, İstanbul 2020, s.89.

${ }^{58}$ Süleyman Numan, a.g.e., s.15.

${ }^{59}$ Sacit Uğuz, “1895 Tarsus Kolera Salgını”, History Studies Prof. Dr. Enver Konukçu Armağanı, C.4, 2012, s. 438.

${ }^{60}$ Evren Dayar, “Antalya Şer’iyye Sicillerindeki Veba ve Kolera ile İlgili Hükümlerin Tahlili (1833-1870)”, OTAM, S. 44, Ankara 2018, s. 35.

${ }^{61}$ Gülden Sarıyıldız, Hicaz Karantina Teşkilatı (1865-1914), Ankara 1996, s.17.

${ }^{62}$ Edhem Necdet, a.g.e., s. 20.

${ }^{63}$ Sinan Kuneralp, “Osmanlı Yönetimindeki (1831-1911) Hicaz'da Hac ve Kolera”, Çev: Münir Atalar, OTAM, S.7, 1996, s.505.

${ }^{64}$ Salgınlar nedeniyle tahaffuzhanelerin ilk kuruluşu II. Mahmud zamanında olmuştur. Padişah, sağlıklı bir toplumun önemini bildiği için sağlık alanında modernleşme taraftarıydı. Fakat ders araç ve gereçleri yetersizdi. Ayrıca 18281831 ve 1834 'te meydana gelen salgın hastalıkların önüne geçilemiyordu. Salgınlar sürdüğ̈ için Padişah uluslararası 
Hindistan, Cava ve Babülmendeb'deki diğer ülkelerin ulaşması için Kamaran ve Ebu Saad tahaffuzhaneleri, Kızıldeniz ve Akdeniz sahillerindeki memleketlerden Suriye, Anadolu, Rumeli ve İstanbul taraflarına gelecekler için Kalazamun ve Beyrut tahaffuzhaneleri, Umman tarafından Irak taraflarına gelecekler için Basra Tahaffuzhanesi ve Karadeniz ve civarındaki memleketlerden gelecekler içinde Kavak Tahaffuzhanesi uygun görülmüştür. ${ }^{65}$

Beşinci kolera salgını 1871 tarihinde meydana gelmiştir. 19 Ağustos'tan 4 Eylül'e kadar tabipler bu hastalığa "beledi kolera" demişler ise de daha sonra aynı hastalığın Bursa ve Rusya'da var olduğu anlaşılınca hastalığın kolera olduğuna karar verilmiştir. 1872 senesinin ilk aylarında hastalık son bulmuştur. Bu salgın da Bursa'dan İstanbul'a gelmiş ve en az 5 bin kişinin ölümüne neden olmuştur. ${ }^{66}$ Günlük ölümler 300 civarında olunca, hastalığa yakalanmaktan çekinen padişah da sarayı bırakıp Yıldız Kasrı'na geçmiştir. ${ }^{67}$

İstanbul'da altıncı kolera salgını 1893 yılında ortaya çıkmıştır. 25 Ağustos'ta birinci vaka Hasköy'de birkaç gün sonra ikincisi Bimarhane'de, Galata'da daha sonra bütün şehirde yayılarak 1 Mayıs 1894 'e kadar hastalık iyice artmış ve 2639 kişiye bulaşarak, 1588 kişinin ölümüne neden olmuştur. Yapılan araştırmalar neticesinde hastalığın biri Odesa'dan diğeri Köstence'den olmak üzere, iki taraftan geldiği anlaşılmıştır. ${ }^{68} \mathrm{Bu}$ salgın beraberinde birtakım yenilikleri de getirmiştir. $\mathrm{Bu}$ yenilikler Bakteriyolojihane-i Şahane ve Tedbirhanelerin açılması, tıbbi istatistiklerin tutulması ve İstanbul sularının bakteriyolojik analizlerinin yapılması olmuştur. ${ }^{69}$

Son olarak 1907 kolerası meydana gelmiştir. Bu vaka Rusya'dan Hicaz'a gitmek üzere gelen hacılardan kaynaklanmıştır. 16 Kasım 1907 tarihinde Tahtakale'de Kebapçı Hanı'nda iki hacının hastalanması üzerine her türlü ilmi araştırmalar uygulanarak hastalığın Asya Kolerası olduğu anlaşılmıştır. Sonunda bu iki vakadan iki ay sonra meydana gelen 12 vaka ile birlikte toplamda 13 vaka ile salgın sona ermiştir. ${ }^{70}$

\section{Sinop'ta Meydana Gelen Kolera Salgını}

Osmanlı Devleti'nin liman kentlerinden biri olan ve Kastamonu Vilayetine bağlı olan Sinop Sancağı, 1892 yılından itibaren kolera salgınları için adeta koruma üssü olarak görev yapmaya başlamıştır. Burada inşa edilen tahaffuzhaneyle Karadeniz'de seyrü sefer halinde olan gemilerin karantina altına alındığı bir merkez olarak Sinop ön plana çıkmıştır. Özellikle Avrupa'dan, Tuna sahillerinden yolcu ile gelecek gemiler için 13 Eylül 1892'den itibaren Kavak veyahut Sinop tahaffuzhanelerinin birinde 5 gün tedbir karantinasina alınmasına karar verilmiştir. ${ }^{71}$ Çünkü 1892 yılında Kuzeybatı Hindistan'da ortaya çıkan ve Hicaz'dan hac yoluyla Osmanlı Devleti'ne ulaşan kolera salgını, 1893-1894 yılları arasında Anadolu'nun çoğu şehir ve kasabalarına yayılmıştır. ${ }^{72}$

Tahaffuzhanenin burada bulunması ve bu tarihlerde kolera salgının Anadolu'nun farklı illerinde hüküm sürmesi Sinop'ta da idarecilerin teyakkuz halinde olmasını gerektirmiştir. Karadeniz sahillerinde dönem dönem artan kolera vakaları, sürekli olarak tecrübeli görevlilere

\footnotetext{
kurallara uymaktan başka çare kalmadığını anlamış ve karantina teşkilatının kurulmasına karar vermiştir. İlk iş İstanbul'da bir karantinahanenin kurulması daha sonrada Anadolu'da gereken yerlerde karantihanenin açılmasına karar verilmiştir. Daha sonra Karantina Meclisi üyelerinden Abdülhak Molla Efendi'nin önerisi ile resmi yazışmalarda usul-u tahaffuz, karantina mekânına da tahaffuzhane denilmesine karar verilmiştir. (Çadırcı, a.g.e., s.38).

${ }^{65}$ G. Sarıyıldiz, a.g.e., s.92.

${ }^{66}$ Süleyman Numan, a.g.e., s.16.

${ }^{67}$ M. Ayar, a.g.e., s. 32.

${ }^{68}$ Süleyman Numan, a.g.e., s.19.

${ }^{69}$ Nuran Yıldırım, "Su İle Gelen Ölüm: Kolera ve İstanbul Suları”, Toplumsal Tarih Dergisi, S. 145, 2006, s.4.

${ }^{70}$ Süleyman Numan, a.g.e.,, s.19.

${ }^{71}$ BOA. Y. PRK. SH 3/65-1, 1 Eylül 1308 (13 Eylül 1892).

${ }^{72}$ S. Uğuz, a.g.m., s. 439.
} 
ihtiyaç duyulmasına neden olmuştur. Çünkü kolerayla mücadelede yetişmiş eleman çok önemliydi. Azalan vaka durumunda görevliler ihtiyaç duyulan başka yerlere nakledilmiştir. Nitekim 10 Şubat 1893 tarihinde Kafkasya, Batum ve Trabzon taraflarında bir aydan fazla bir süre kolera görülmemesi üzerine, Sinop'ta sadece bir doktor, iki gardiyan ve bir makinistin bırakılması istenmiş ve Bahriyeden İbrahim Paşa, Meclisi Sıhhiye azası olan Miralay Nuri Bey ve memurların İstanbul'a dönmeleri emredilmiştir. ${ }^{73}$

Ekim 1893 tarihinde İrade-i Mahsusa'nın Arselan isimi vapuruyla Sinop'a gelen Ayancik sakinlerinden biri şehir içinde hastalanınca tahaffuzhane ve belediye doktorları tarafından muayene edilmiştir. Yapılan muayene neticesinde hastanın kolera belirtileri gösterdiği saptanmış ve üç gün sonra vefat etmiştir. Bunun üzerine hastalık mahali kordon altına alınarak vakanın Sinop'ta yayılmasının önüne geçilmiştir. ${ }^{74}$ 2-6 Kasım 1893 tarihleri arasında Sinop'a bağlı Darı̈̈zü ve Korucuk köylerinde bazı kişilerin hastalanıp vefat etmesi üzerine, buralar hemen kordon altına alınmıştır. Hastalığın durumu İstanbul'a telgrafla bildirilince durumun kolera olup olmadığı, hastalığın ne suretle bulaştığı ve ne gibi tedbirler alındığına dair Kastamonu mutasarrıflığından malumat sorulmuştur. ${ }^{75}$ Darı̈̈zü Köyü'nde bir vefat ve dört bulaşık hasta tespit edilmiş, Korucuk Köyü'nde ise erkek ve kadın olmak üzere dört kişi vefat etmiştir. İki üç kişide daha kolera belirtileri de baş gösterince, buraların kordon altında tutulduğu Sinop mutasarrıflığı tarafından bildirilmiştir. Ayrıca Sinop merkezi dışında Durağan Nahiyesi’nin İncir Köyü’nde bir kişide hastalık görülmüş, bunun kolera olup olmadığı tam tespit edilememiştir. ${ }^{76}$ Koleranın ortaya çıkmasıyla beraber, vakanın artmaması için gerekli tedbirler alınıp durum Sıhhiye Nezareti'ne telgrafla bildirilmiştir. Bulaşık olanlara ne gibi yardımlar yapıldığı hastalığın kolera olduğu ve Sinop'a kaç saat mesafede olduğu, Sinop Mutasarrıflığı tarafından bildirilmiştir. ${ }^{77}$ Ayrıca Sihhiye Nezareti'ne yazılan telgrafla koleranın dışardan bulaşmadığı, hastaların birbirleriyle olan etkileşimlerinden dolayı hastalık baş göstermiş, gereken yardım malzemesinin yanında Boyabat Belediyesi tarafından da doktor sevki yapıldığı bildirilmiştir. ${ }^{78}$

1893 yılının Kasım ayında Sinop Tophanesinde bir askerin hastalanıp yapılan muayene neticesinde kolera olduğu tespit edilmiştir. Asker hastalandiktan on iki saat sonra vefat edince, durum Kastamonu Mutasarrıflığına bildirilmiştir. Burada hastalığın farklı yerlere bulaşmadığ 1 ve gerekli kordon tedbirlerinin alındığına dair malumat verilmiştir. ${ }^{79}$ Asker hastalandığ 1 sırada doktorlar gerekli muayeneyi yapıp kolera teşhisini koyduktan sonra, hastanın vefatı üzerine hastahanenin her tarafi dezenfekte işlemine tabi tutulmuştur. ${ }^{80}$ Osmanlı Hükümeti, koleranın şehrin farklı yerlerine dağılmaması için, yerel idarecilerden azami ölçüde dikkatli olmalarını istemekteydi. Topçu neferinin vefatı üzerine Sinop Mutasarrıfinın Kastamonu Vilayetine bildirdiği telgraf, doğruca Sıhhiye Nezaretine gönderilmiştir. Sihhiye Meclisi'nde okunan telgraf ve alınan kararla hastanın vefatından üç gün sonra herhangi bir vakanın görülmemesi üzerine gerekli tedbirlerin alınmasıyla beraber, şimdilik başka bir şey yapılmamasına karar verilmiştir. ${ }^{81}$ Sinop Mutasarrıfı Reşid Paşa, askerin vefat ettiği yerden başka, diğer askerlerin de dezenfekte

\footnotetext{
${ }^{73}$ BOA, BEO /153 /11427, 29 Kanun-i Sani 1308 (10 Şubat 1893).

${ }^{74}$ İsmail Yaşayanlar, Sinop, Samsun ve Trabzon'da Kolera Salgınları, Karantina Teşkilatı ve Kamu Sağll̆̆g Hizmetleri (1876-1914), ( Yayımlanmamış Doktora Tezi), Uludă̆ Üniversitesi, Sosyal Bilimler Enstitüsü, Bursa 2015, s.79.

75 BOA, A. MKT. MHM 562/ 32/1-2, 9 Teşrin-i Sani 1309 ( 21 Kasım 1893).

${ }^{76}$ BOA, A. MKT. MHM 562/ 32/3-1, 8 Teşrin-i Sani 1309 ( 20 Kasım 1893).

77 BOA, A. MKT. MHM 562/ 32/3-2, 8 Teşrin-i Sani 1309 ( 20 Kasım 1893).

${ }^{78}$ BOA, A.MKT. MHM 562/ 32/4-2, 12 Teşrin-i Sani 1309 ( 24 Kasım 1893).

${ }^{79}$ BOA, A. MKT. MHM 562/ 32/5-2, 9 Teşrin-i Sani 1309 ( 21 Kasım 1893).

${ }^{80}$ BOA, A. MKT. MHM 562/ 32/7-1, 8 Teşrin-i Sani 1309 ( 20 Kasım 1893).

${ }^{81}$ BOA, A. MKT. MHM 562/ 32/9-1, 10 Teşrin-i Sani 1309 (22 Kasım 1893).
} 
edildiği ve eşyasının da gerekli kurallar çerçevesinde dezenfektesi yapılmakla birlikte, kasabada

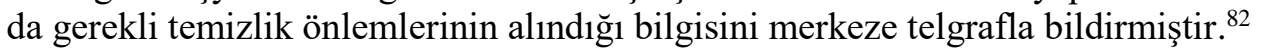

\section{Koleraya Karşı Alınan Tedbirler}

Osmanlı Devleti, 1831 yılında kolerayla karşılaşınca karantina teşkilatının kurulması gündeme gelmişti. Fakat karantina hakkında bilimsel esaslara dayalı bilgiyi kimse bilmiyordu. İstanbul, İzmir gibi şehirlerde yayılan veba salgınları çok sayıda kişinin ölmesine neden olunca karantina teşkilatının kurulmasına hız verilmiştir. ${ }^{83} \mathrm{Bu}$ doğrultuda şer'i fetva alındıktan sonra Karantina Tatbikinin uygun biçimde Takvim-i Vekayi'de ilan edilerek icraata başlaması istenmiştir. ${ }^{84} 1835$ yılında Karantina uygulaması daha sistemli hale gelmeye Çanakkale'de başlamıştır. Burada karantina çadırları kurulmuş, İstanbul'a gidecek gemiler, bir süre bekletilmeye başlanmıştır. ${ }^{85}$ Sultan Abdülmecid, tahta geçtikten sonra salgın hastalıklarla mücadele için bir dizi kararlar almıştır. Bu kararların bazıları şunlardır: Mahalle muhtarları ve imamlar mahallelerinde veba veya başka bir hastalık görünce durumu derhal karantina meclislerine bildireceklerdir. Ölen olunca karantinahaneden izin alınmadan herhangi bir işlem yapılmayacaktır. Hastalığın görüldüğ̈̈ ev veya mahallelerde karakol kurularak karantinahaneye alınacaktır. ${ }^{86}$ Ayrıca salgın hastalıklarla mücadele için Belediyelerde, Belediye Tabipliği oluşturulmuş, sağlıkla ilgili sorunların çözümü görevi de belediyelere bırakılmıştır. ${ }^{87}$ Hastalıklara karşı korunma tedbirleri 19. yüzyılla beraber kuramsallaşmaya başlamasına rağmen, yeteri kadar eleman olmayışı batılılardan yardım almayı gerektirmiş kolera ile mücadelede yabancı bilim adamları ve hekimler getirtilmiştir. 1893 yılındaki kolera vakasında İstanbul'da bulunan hekimler, hastalığın kolera olup olmadığı konusunda şüpheye düşmüşlerdir. Bu şüphe devam ederken kolera İstanbul'da yayılmaya devam etmiştir. Bu esnada Dr. Chantemesse'nin İstanbul'a gelmesi memnuniyetle karşılanmış ve uygun laboratuvar ortamı hazırlanıp, hastalardan alınan örnekleri test etmesi istenmiştir. Yapılan test sonucunda İstanbul'daki salgının kolera olduğu ispatlanmıştır. ${ }^{88}$ Avrupalılar koleranın kendi ülkelerine Hicaz yoluyla geldiğini iddia edip Osmanlı Devleti'ne devamlı protestolarını iletmekteydiler. 1893 y1lında Hicaz'da meydana gelen büyük kolera salgınında da Osmanlı Devleti Avrupalıların suçlamaları ve müdahalesine maruz kalmıştır. ${ }^{89} \mathrm{Bu}$ doğrultuda karantina merkezlerine kendi delegelerini yerleştirmişlerdir. Çünkü Osmanlı Devleti'nde bu konuda uzman bulunmadığından, Avrupa'dan uzmanlar getirtilmiştir. Başlangıçta karantina meclislerine geçici olarak dâhil edilen sefir vekillerinin statüleri, zamanla daimi hale dönüşmüş ve karantina meclisleri milletlerarası bir hale bürünmüştür. Bu durum da devletin aleyhine olmuştur. ${ }^{90}$

1892 yılında kolera, Batı Avrupa'ya İran üzerinden yayılmaya başlayınca, Osmanlı Devleti de kara yoluyla Osmanlı Devleti'ne gelecekler için karantina mevkileri belirlemeye başlamıştır. Bu mevkiler Edirne'de Cisrimustafapaşa ve Kosova' da Zibefçe'ydi. ${ }^{91}$ Buralarda ivedi bir şekilde çadırlar kurularak ve etüv ${ }^{92}$ makineleri yollanarak karantina uygulamasına

\footnotetext{
82 BOA, A. MKT. MHM 562/ 32/11-1, 10 Teşrin-i Sani 1309 (22 Kasım 1893).

${ }^{83}$ Nuran Yıldırım, "Osmanlı Coğrafyasında Karantina Uygulamalarına İsyanlar: Karantina İstemezük”, Toplumsal Tarih, 2006, S. 150, s.18-27.

${ }^{84}$ G. Sarıy1diz, a.g.e., s.7.

${ }^{85}$ Gülden Sarıy1dız, "Karantina", TDV İslam Ansiklopedisi, C. 24, 2001, s.464.

${ }^{86}$ M. Çadırc1, a.g.e., s.39.

${ }^{87}$ M. Emin Yolalıcı, "Osmanlılarda Çağdaş Belediyecilik”, Türkler Serisi, Editör: Hasan Celal Güzel- Salim Koca, Yeni Türkiye Yayınları, Cilt 13, Ankara 2002, s.1346.

${ }^{88}$ Nuran Yıldırım, “1893'te İstanbul'da Kolera Salgını”, Tarih ve Toplum Ansiklopedik Dergi, S. 129, 1994, s.16.

${ }^{89}$ G. Sarıyıldı, "Hicaz Karantina...", s.68.

${ }^{90}$ G. Sarıyıldız, a.g.m., s. 464.

${ }^{91}$ M. Ayar, a.g.e., s. 40.

92 Mikroorganizmaların sebep olduğu salgın ve bulaşıı hastalıklardan dezenfekte yöntemiyle kurtulmak için çeşitli yöntemler ve araçlar geliştirilir. 100-150 derecedeki basınçlı su buharının dezenfeksiyon için en etkili yöntem olduğu
} 
geçilmiştir. ${ }^{93}$ Yine bu tarihte kolera Rusya'nın büyük kısmına yayılmış ve kuzeyden Karadeniz sahillerine yaklaşmıştır. Bu durum Osmanlı Devleti'ni tedirgin etmekte ve Rusya'dan gelen gemilere Kavak ve Sinop tahaffuzhanelerinde karantina uygulanmaktayd1. ${ }^{94}$ Sinop Tahaffuzhanesi ${ }^{95}$, 1892 kolera salgını başlamadan önce, Sıhhiye İdaresince yapılmasına karar verilmiș ve 24 Ağustos 1892 'de hizmet vermeye bașlamıștır. ${ }^{96}$ Karadeniz'de karantina ve dezenfeksiyon noktası haline gelen Sinop, İstanbul ve Hicaz'in sıhi durumunun denetlendiği önemli bir kuruluş olmuştur. ${ }^{97}$ Karadeniz kıyılarından gelen gemiler önce Sinop'a gelip karantina müddetini dolduruyorlar, ardından Kavak Tahaffuzhanesine geçip genel bir muayeneden sonra Karadeniz'e açılmalarına izin veriliyordu. Aksi takdirde, geçiş belgesi olan pratikayı alamayanlar tahaffuzhaneden çıkamazd $1 .{ }^{98}$ Çünkü Rusya' da ve Karadeniz sahillerinde yayılım gösteren kolera salgınları, Osmanlı Devleti'ni sürekli tedirgin etmekteydi. Devlet, devamlı teyakkuz halinde olup hastalığın ülkeye yayılmaması için Sıhhiye Meclisi tarafından tedbirler alınmaktaydı. Bu tedbirler esnasında ordu birlikleri kordon mahalline veya sınır birliklerine yardıma gönderilmiştir. Rusya'daki kolera vakasının yayılması hız kazanınca, tahaffuz tedbirleri kapsamında Narman ve Pasin kordonlarının takviyesi için Erzurum'da bulunan 25. Alayın 3. Taburu hudut üzerine sevk edilmiştir. Ayrıca Hopa'da müteşekkil karantina kordonu için Rize'de bulunan Nizamiye Bölüğü Hopa'ya ve Trabzon'da bulunan Nizamiye taburundan bir bölük de Rize'ye sevk edilmiştir. Hudutlarda oluşturulmuş tahaffuzhaneler için Beyazıd ve Diyadin'den yeteri kadar asker verilmesi ve giden askerlerin yerine de 30. Alayın Erzurum'da bulunan 2. Taburu Beyazit'a gönderilmiştir. ${ }^{99}$

Koleranın görüldüğü Romanya da Osmanlı Devleti için riskli yerlerdendi. Bu nedenle 4

Ağustos 1893'ten itibaren Romanya'nın Karadeniz sahillerinde ve Tuna Nehrinden gelen gemilere karantina tedbirleri uygulanmaya başlanmıştır. Hastalığın İstanbul'a bulaşma riskine karşın Romanya gemilerinin Sinop Tahaffuzhanesi'nde 10 gün boyunca karantina altında kalmasına karar verilmiş ve Sinop Tahaffuzhanesi'nin güvenliği için de karadan askerler görevlendirilmiştir. Deniz tarafından ise bir beylik gemisi, bir filika ve bir istimbotun

anlaşılmış ve giysiler ile eşyalar için etüv makineleri tasarlanmıştır. Geneste ve Herscher fabrikatörlerin tasarımı olan etüvlerin mikroorganizmaları seri bir şekilde öldürmesi, 110-120 dereceden yüksek 1sı gerektirmemesi, giysi, eşya ve döşemelerin rengini değiştirmemesi gibi nedenlerle tercih edilir olmuşlardır. Bu nedenle kolerayla mücadelede başta hastaneler olmak üzere, karantinahaneler, belediyeler ve gemilerde etüv makineleri kullanılmıştır. (Nuran Yıldırım, "Tersane-i Âmire Fabrikalarında Tebhir Makinesi/Etüv Üretimi ve Kullanımı”, Dünü ve Bugünü ile Haliç Sempozyumu Bildirileri, 22-23 Mayıs 200, Editör: S.F.Göncüoğlu, Kadir Has Üniversitesi Yay. İstanbul 2004, s. 422.)

${ }^{93}$ M. Ayar, a.g.e., s. 40

${ }^{94}$ M. Ayar, a.g.e., s.45.

${ }^{95}$ Koleranın Karadeniz yoluyla İstanbul'a ulaşmasını engellemek için Sinop'ta tahaffuzhanenin yapılması şarttı. Bu nedenle Sinop tahaffuzhanesinin yerini tespit etmek için sıhhiye heyeti bölgeye gönderilmiştir. Yapılan incelemeler neticesinde tahaffuzhanenin bir an önce yapılmasına karar verilmiş ve inşaat için gerekli olan yüz nefer ile beş zabit çadırı ve on abdesthane çadırının Sinop'a gönderilmesine karar verilmiştir. (Erol Karcı, "Kolera İle Mücadelede Örnek Bir Sağlık Müessesesi: Sinop Tahaffuzhanesi ve Faaliyetleri (1892-1908)”, XVII. Türk Tarih Kongresi, C. IVV. Kısım, Ankara 2014, s.1881.) 1892 yılında inşası tamamlanan Sinop Tahaffuzhanesinde, kordon hizmetini sağlamak için askerlerin bulunması gerekmekteydi. Fakat yeteri kadar askerin bulunmadığını söyleyen Sıhhiye azası Miralay Nuri Bey, Sinop kalesinde bulunan topçu neferinin yalnız 167 kişiden ibaret olduğu ve bunların da 10 mevkiye dağılmış olmaları nedeniyle tahaffuzhane kordonuna yalnız 20 nefer gönderebileceklerini beyan etmiştir. Bunun üzerine Sinop kumandanlığından alınan telgraf neticesinde bu durum Erkân-1 Harbiye'de görüşülmüş ve redif taburlarından 100 neferlik bir bölüğün Sinop tahaffuzhanesinde görev yapmasına karar verilmiştir. BOA. Y.MTV 65/23, 65/23-3, 19 Temmuz 1308 (22 Kasim 1893).

${ }^{96}$ M. Ayar, a.g.e., s.68.

97 İsmail Yaşayanlar, "Hicaz Yolunda Kolera: Rusya Müslümanlarının Kullandığ 1 Karadeniz Hac Yolu ve Koleranın Yay1lımına Etkisi”, Avrasya İncelemeleri Dergisi, IV/2, 2015, s.185.

${ }^{98}$ M. Ayar, a.g.e., s.413.

${ }^{99}$ BOA. Y.MTV 65/23-02.01, 19 Temmuz 1308 (22 Kasım 1893). 
gönderilmesine karar verilmiştir. ${ }^{100}$ Kolera tedbirleri kapsamında Hükümet ülkeye giriş çıkışları yasaklayabilmekteydi. 5 Ağustos 1893 tarihinde Bükreş elçisinin Osmanlı Devleti'ne gönderdiği telgrafta 3000 kadar Osmanlı vatandaşının İbrail ve Sünne'de çektikleri sıkıntılardan dolay $1^{101}$ İstanbul'a gelmek için beklediği ve bu kişilerin İstanbul'dan önce Sinop Tahaffuzhanesinde karantinaya alınması konuşulmuşken, bu kadar kalabalığın Sinop'a gelmesi tehlikeli olacağından, devlet bu kişilerin ülkeye girmesine izin vermemiştir. ${ }^{102}$ Alınan bu tedbirlerin nihai hedefi hastalığın başkente ulaşmasını engellemekti. Salgın Trabzon'da yayılmaya başlayınca, hastalığın Anadolu'nun farklı yerlerine dağılmaması için ordu sürekli teyakkuz halindeydi. Samsun, Polathane ve Hopa mevkilerinin arka kısımlarında bulunan önemli geçitlere 2. Kordon bırakılarak Polathane'ye bir bölük piyade askerinin acilen yollanması için 4. Orduya emir verilmiştir. ${ }^{103}$

1893 yılında Osmanlı Hükümeti’nin tüm vilayetlere gönderdiği uyarı emrinde temizliğe azami ölçüde dikkat edilmesi ve ahalinin de üzerine düşen temizlik ve sağllk konusuna özen göstermeleri istenmiştir. ${ }^{104}$ Nitekim bu o kadar da kolay olmayabiliyordu. Adana'da salgın ve hastalıkla mücadelenin devam ettiği sırada hocalar tenzifat memurlarına direnmeye başlamışlardır. Memurlar ve hocalar arasındaki anlaşmazlığın sürdüğü sırada Bağdat'tan gelen Alaybeyi Said, hocalara sıhhi konularda telkinde bulunmasına rağmen, bunu dikkate almayan ve rahatsız olan hocalar durumu çarpıtıp Said Beyi görevden aldırmışlardır. ${ }^{105}$ Kolerayla mücadelede başarı gösteren idareciler de ödüllendirilmiştir. Şubat 1893 tarihinde Sinop Mutasarrıfı Reşid Paşa'nın kolerayla mücadelede gerekli tedbirleri alıp, tahaffuzhanenin inşasında ve hapishanenin nizamı esnasında gösterdiği gayretlerinden dolayı rütbesinin bir derece arttırılmasına ve beratının takdim kılınması için Kastamonu vilayetine emir gönderilmiştir. ${ }^{106}$ İdarecilerin yanında şehirde kolerayla mücadelede fayda sağlayan Kavizade Hasan ve Şükrü Zade Numan Bey, Altun oğlu İlyas ve Ümeradan İbrahim oğlu Ömer efendiler, defterlerde yazılı olan kayıkçı taifesi ve zabitanlar da ödüllendirilmiştir. ${ }^{107} 1894$ senesinde Erzincan'a bağlı köylerde koleraya yakalananları tedavi etmede gösterdikleri gayretten dolayı Yüzbaşı Tahir ve Şükrü efendilerin de bir misli zam maaş ve harcırah ile ödüllendirilmişlerdir. ${ }^{108}$

Sıhhiye komisyonunun aldığı kararla, kolera mikrobuna karşı halkı bilinçlendirmek için tedbirler alınması kararlaştırılmıştır. Bu doğrultuda Türkçe, Ermenice ve Rumca risaleler hazırlanıp halkın hijyen konusunda ne yapmaları gerektiğine dair bilgilendirmeler yapılmıştır. ${ }^{109}$ Tuvalet zeminlerine sert taş konulması ya da çimento dökülmesi, tuvalet çukurlarına kireç atılması, çamaşır sularının sokaklara serpilmemesi, han odalarının kireçle badana yapılması, çamaşırhanelerin pis sularının ana lağımlara akıtılması, önünden lağım geçmeyen evlerin bahçesi yoksa çamaşır yıkanmasının yasaklanıp, çamaşırların komşularda yıkanması gibi görüşler bildirilmiştir. ${ }^{10}$ Kolera salgını sudan geçen bir hastalık olduğu için, insanların suları kaynatarak içmeleri istenmiştir. ${ }^{111}$ Şehir suları kuyulardan ve kaynak sularından ise geçtiği yerlerdeki bütün pisliklerden arınmış olmalıdır. Kaynakların etrafında yerleşme kesinlikle men edilmelidir. Kaynağın etrafında çayır, tarla bulunmamalı ve su kuyuları derin ve tuvaletlerden uzak

\footnotetext{
${ }^{100}$ M. Ayar, a.g.e., 2007, s. 50

${ }^{101}$ BOA. Y. PRK. HR 18/2-1, 5 Ağustos 1309 (17 Ağustos 1893).

102 BOA, BEO /258 /19334, 4 Ağustos 1309 (16 Ağustos 1893).

${ }^{103}$ BOA. Y.MTV 65/23-02.01, 19 Temmuz 1308 (22 Kasim 1893).

${ }^{104}$ M. Ayar, a.g.e., s. 90 .

${ }^{105}$ Kurtuluş Demirkol, “Adana ve Kolera”, Dumlupınar Üniversitesi Sosyal Bilimler Dergisi, S. 56, 2018, s.145.

106 BOA, DH. MKT $16 / 40,10$ Şubat 1892 (22 Şubat 1894).

107 BOA, DH. MKT 15/12, 14 Temmuz 1309 ( 26 Temmuz 1893).

${ }^{108}$ Abdulkadir Gül, "XIX. Yüzyılda Erzincan Kazasında Salgın Hastalıklar ( Kolera, Frengi, çiçek ve Kızamık)", A.Ü. Türkiyat Araştırmaları Enstitüsü Dergisi, S.41, 2009, s.253.

${ }^{109}$ A. Gül, a.g.m., s.246.

${ }_{110}$ M. Ayar, a.g.e., s. 300

${ }^{111}$ Oktay Bozan, "Diyarbakır Vilayeti'nde 1894-1895 Kolera Salgını ve Etkileri”, Türk Dünyası Araştırmaları Dergisi, S. 218,2015 , s. 226.
} 
olmalıdır. ${ }^{12}$ Osmanlı Devleti'nde koleranın yayılmasında en önemli etkenlerden birisi de lağım sisteminin olmamasıdır. İçilecek suların geçtiği sağlam kanallar mevcut olmadığından yağmur sularıyla beraber toprağa sızan sular ve lağım çukurlarının suları birbirine karışıp içme sularına karışmıştır. Bu da koleranın yayılmasında büyük bir rol oynamıştır. ${ }^{113} 1893$ tarihinde Eskişehir'de kolera salgını meydana geldiği vakit, salgının Porsuk Çayı'ndan kaynaklandığı gözlemlenmiştir. Çünkü halk burada hem çamaşır yıkayıp hem de içme suyunu temin etmiştir. Porsuk Çayı'ndan su içilmesi men edilince iyileşmeler azami derecede olmuştur. ${ }^{114}$

\section{Sonuç}

Yakınçă̆'ın başlarına kadar Hindistan'a ait bölgesel bir hastalık olan kolera, değişen teknolojiler, ulaşım araçlarının çeşitlenmesi, askerler, ticaret gibi nedenlerle 1817'den sonra bölge dışına çıkarak, uluslararası bir salgına dönüşmüştür. Hastalık karşısında aciz kalan insanoğlu birtakım tedavi ve karantina yöntemleri deneyerek bu hastalıkla başa çıkmaya çalışmışlardır. Fakat kolera, yayılımını sürdürerek, Amerika ve Kanada'ya kadar ulaşmıştır. Yolların geçiş güzergâhında bulunan Osmanlı Devleti'ne hastalığın bulaşması kaçınılmazdı ve ilk vaka 1821 yılında Halep civarında görülmüştür.

Salgın gibi nedenlerle devlet sağlık sisteminde yenileşme çabalarına girmiş ve oluşturulan tahaffuzhanelerle salgınları kontrol altına almaya çalışmıştır. Fakat yetişmiş doktor eksikliği, hastalık konusunda yeteri kadar bilginin olmaması Osmanlı Devleti’ni birtakım sıkıntılara sokmuş ve batıdan yardım almasını gerektirmiştir. Salgında mücadelede karantina tedbirleri alınarak kordonlar oluşturulmuştur. Bu kordonlar neticesinde üretim düşmüş ve hayat pahalılığ ortaya çıkmıştır. Ölüm korkusu ve geçim sıkıntısı gibi nedenlerle insanlar göç etmişlerdir. Hastalıkla mücadelede işi zorlaştıran durumlardan biriside halkın cehaleti ve kaderci yaklaşımıdır. Yeteri kadar hijyen ve hassasiyeti göstermeyen kişiler arasında hastalığın kırıcı etkisi daha fazla olmuştur. Özellikle halk arasında koleranın doktorlar tarafindan bilerek ortaya atıldığı ve doktorların hastaları öldürmek istediğine dair söylentiler de yayılmıştır.

Salgın hastalıklarla mücadele konusunda tahaffuzhanelerin çok önemli bir yeri vardı. Karadeniz sahillerinde koleranın artması İstanbul'un sağlık açısından güvenliğini tehlikeye düşürüyordu. Bu nedenle Karadeniz'de Kavak tahaffuzhanesinin dışında yeni bir tahaffuzhanenin açılmas1 gerekli görülmüştür. 24 Ağustos 1892'de açılan Sinop Tahaffuzhanesi, İstanbul'a gidecek gemilerin karantinaya alındığı işlek bir limana dönüşmüştür. Fakat bu kadar gemi trafiğinin arasında 1893-1894 yıllarında Sinop'ta kolera vakasının çok fazla görülmemesi memnuniyet vericidir. Çünkü bu yıllarda kolera Osmanlı Devleti'nin neredeyse tamamına yayılmıştır. Ele aldığımız belgelerden de anlaşılacağı üzere birkaç vaka dışında büyük çapta olaylar yaşanmamıştır. Bunda yerel idarecilerin rolü, uygulamış oldukları dezenfekte işlemleri, oluşturulan kordonlar, tahaffuzhanenin şehir merkezinin dışında olması gibi unsurların büyük rolü olmuştur.

\section{Kaynaklar}

\section{1-T.C. Cumhurbaş̧kanlığı Devlet Arşivleri Başkanlığı Osmanlı arşivi (BOA)}

Sadâret Mektubî Kalemi Mühimme Kalemi (Odası) Belgeleri ( A. MKT. MHM):

BOA, A. MKT. MHM, 562/32/1-2, 9 Teşrin-i Sani 1309 ( 21 Kasım 1893).

BOA, A. MKT. MHM ,562/32/3-1, 8 Teşrin-i Sani 1309 ( 20 Kasım 1893).

\footnotetext{
112 Süleyman Numan, a.g.e., s.148.

${ }^{113}$ Edhem Necdet, a.g.e., s. 50.

${ }^{114}$ Süleyman Numan, a.g.e., s.27.
} 
BOA, A. MKT. MHM ,562/32/3-2, 8 Teşrin-i Sani 1309 ( 20 Kasım 1893).

BOA, A. MKT. MHM ,562/ 32/4-2, 12 Teşrin-i Sani 1309 ( 24 Kasım 1893).

BOA, A. MKT. MHM ,562/ 32/5-2, 9 Teşrin-i Sani 1309 (21 Kasım 1893).

BOA, A. MKT. MHM ,562/ 32/7-1, 8 Teşrin-i Sani 1309 ( 20 Kasım 1893).

BOA, A. MKT. MHM ,562/ 32/9-1, 10 Teşrin-i Sani 1309 ( 22 Kasım 1893).

BOA, A. MKT. MHM ,562/ 32/11-1, 10 Teşrin-i Sani 1309 ( 22 Kasım 1893).

\section{Bâb-ı Âlî Evrak Odası ( BEO):}

BOA, BEO,153 /11427, 29 Kanun-i Sani 1308 ( 10 Şubat 1893)

BOA, BEO, 258 /19334, 4 Ağustos 1309 ( 16 Ağustos 1893).

\section{Dâhiliye Nezâreti Mektubî Kalemi (DH. MKT):}

BOA, DH, MKT, 16/40, 10 Şubat Sene 1309 ( 22 Şubat 1894).

BOA, DH, MKT, 15/12, 14 Temmuz 1309 ( 26 Temmuz 1893).

\section{Mütenevvî Maruzat Evrakı (Y.MTV):}

BOA, Y. MTV,65/23, 19 Temmuz 1308( 22 Kasim 1893).

BOA, Y. MTV,65/23-02.01, 19 Temmuz 1308( 22 Kasim 1893).

BOA, Y. MTV,65/23-3, 19 Temmuz 1308( 22 Kasım 1893).

\section{Yıldız Perakende Evrakı Hariciye Nezâreti Maruzâtı ( Y.PRK.HR):}

BOA, Y. PRK. HR, 18/2-1, 5 Ağustos 1309 ( 17 Ağustos 1893).

BOA, Y. PRK. HR, 18/2-2, 16 Ağustos 1309 ( 28 Ağustos 1893).

\section{Yıldız Perakende Evrakı Sıhhiye Nezâreti Maruzâtı (Y.PRK.SH):}

BOA, Y. PRK. SH, 3/65-, 1 Eylül 1308 ( 13 Eylül 1892).

\section{2- Kitap ve Makaleler}

Altınöz, İsmail, “Osmanlı Toplum Yapısı İçinde Çingeneler”, Türkler Ansiklopedisi, Editör: Hasan Celal Güzel-Salim Koca, Yeni Türkiye Yayınları, C. 10, Ankara, 2002, s. 773-796.

Arslan İbrahim, Karagül Soner, "Küresel Bir Tehdir ( COVID19 Salgını) ve Değişime Yolculuk”, Üsküdar Üniversitesi Sosyal Bilimler Dergisi, S. 10, İstanbul 2020, s.1-36.

Ayar, Mesut; Osmanlı Devletinde Kolera İstanbul Örneği (1892-1895), İstanbul, 2007.

Baytimur S. Oğuz - Tatar, Özcan; “Osmanlı Devleti’nde Çekirge İstilaları ve Sosyo-Ekonomik Hayata Etkileri (1789-1839), Avrasya Uluslararası Araştırmalar Dergisi, C. 8, S. 23, Türkiye 2020, s. 325-347.

Bozan, Oktay, “Diyarbakır Vilayeti'nde 1894-1895 Kolera Salgını ve Etkileri”, Türk Dünyası Araştırmaları Dergisi, S. 218, İstanbul 2015, s. 219-240.

Cabi Ömer Efendi, Cabi Tarihi, C. II. Hazırlayan. M. Ali Beyhan, Ankara, 2003.

Çadırc1, Musa, Tanzimat Sürecinde Türkiye Anadolu Kentleri, Ankara, 2011. 
Çavdar Necati - Karcı, Erol, "XIX. Yüzyıl Osmanlı Sağlık Teşkilatlanmasına Dair Bibliyografik Bir Deneme", Turkish Studies, Volume 9/4, Spring 2014, s. 255-286.

Dayar, Evren, “Antalya Şer'iyye Sicillerindeki Veba ve Kolera ile İlgili Hükümlerin Tahlili (1833-1870)", OTAM, S. 44, Ankara 2018, s. 19-44.

Demirkol, Kurtuluş, “Adana ve Kolera”, Dumlupınar Üniversitesi Sosyal Bilimler Dergisi, S. 56, Kütahya, 2018, s.141-156.

Diyanet İşleri Başkanlığı, Kur'an-ı Kerim Meali, 14. Baskı, Ankara 2012.

Edhem Necdet, Kolera Tabibi, İstanbul 1326.

Erler, M. Yavuz, "XIX. Yüzyıldaki Bazı Doğal Afetler ve Osmanlı Yönetimi” Türkler Ansiklopedisi, Editör: Hasan Celal Güzel, Salim Koca, Yeni Türkiye Yayınları, Cilt 13, Ankara 2002, s.1384-1400.

Gül, Abdulkadir, "XIX. Yüzyılda Erzincan Kazasında Salgın Hastalıklar ( Kolera, Frengi, Çiçek ve Kızamı)", A.Ü. Türkiyat Araştırmaları Enstitüsü Dergisi, S.41, Erzurum 2009, s.239270.

Hamlın, Cyrus, Türkiye'deki Misyonerlik Faaliyetleri, Çev. Arzu Taşcan, İstanbul 2015.

Karc1, Erol, "Kolera İle Mücadelede Örnek Bir Sağlık Müessesesi: Sinop Tahaffuzhanesi ve Faaliyetleri (1892-1908)", XVII. Türk Tarih Kongresi, C. IV- V. Kısım, Ankara 2014, s.1871-1893.

41

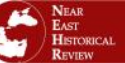

$11 / 1$

January 2021

Karcı, Erol, “Osmanlı Devleti’nde Bakteriyoloji Öğretiminin Öncüsü Doktor Hamdi Aziz Paşa ve 1902-1904 Irak Kolerasına Dair Tespitler”, Selçuk Üniversitesi Türkiyat Araştırmaları Dergisi, S.49, Konya 2020, s.399-417.

Imıl, Muhittin, "Kutsal Dünyanın Virüsle İmtihanı: Post-Pandemik Dönem ve Din", Dini Araştırmalar Dergisi, C.23, S. 57, Ankara 2020, s.65-94.

Kılıç, Orhan, Eskiçağdan Yakınçağa Genel Hatlarıyla Dünyada ve Osmanlı Devleti'nde Salgın Hastalıklar, Elazığ 2014.

Kılıç, Orhan, "16-18. Yüzyıllarda Balkan Şehirlerinde Yaşanan Veba Salgınları ve SosyoEkonomik Etkileri”, Osmanlı Dönemi Balkan Şehirleri, C. 3, Ankara 2017, s.1181-1209.

Kuneralp, Sinan, “Osmanlı Yönetimindeki ( 1831-1911) Hicaz'da Hac ve Kolera” Çev. Münir Atalar, OTAM, S.7, Ankara 1996, s. 497-511.

Memiş, Ekrem, Eskiçağ Türkiye Tarihi, 15. Bask1, Bursa 2020.

Olivier, Antonie, Türkiye Seyahatnamesi (1790 Yıllarında Türkiye ve İstanbul), C.1, Çev. Oğuz Gökmen, Ankara 1977.

Onul, Behiç, Kolera, Ankara Üniversitesi Tıp Fakültesi Yayını, S. 249, Ankara 1971.

Panzac, Daniel, Osmanlı Imparatorluğunda Veba (1700-1850), Çev. Serap Y1lmaz, İstanbul 1997.

Porta, Miquel, A Dictıonary of Epidemiology, Fifth Edition, Oxford University Press, , 2008.

Sarıyıldız, Gülden, Hicaz Karantina Teşkilatı (1865-1914), Ankara 1996.

Sarıyıldı, Gülden, "Karantina”, TDV İslam Ansiklopedisi, C. 24, İstanbul 2001, s.463-465.

Süleyman Numan, Kolera, Kostantiniyye, Matbaa-i Ebuzziya, Sene 1326. 
Uğuz, Sacit, “1895 Tarsus Kolera Salgını”, Hıstory Studies Prof. Dr. Enver Konukçu Armağanı, C.12, 2012, s. 437-448.

Yaşayanlar, İsmail, Sinop, Samsun ve Trabzon'da Kolera Salgınları, Karantina Teşkilatı ve Kamu Să̆lığı Hizmetleri (1876-1914), ( Yayımlanmamış Doktora Tezi), Uludağ Üniversitesi, Sosyal Bilimler Enstitüsü, Bursa 2015.

Yaşayanlar, İsmail, "Hicaz Yolunda Kolera: Rusya Müslümanlarının Kullandığı Karadeniz Hac Yolu ve Koleranın Yayılımına Etkisi”, Avrasya İncelemeleri Dergisi, IV/2, İstanbul 2015, s.178-203.

Yaşayanlar, İsmail, Bir Kent, İki Salgın: Antep 'te 1848 ve 1890 Kolera Epidemileri, Uluslararası Gaziantep Tarihi Sempozyumu Milli Mücadele Döneminde Gaziantep Bildiri Metinleri Kitab1, Gaziantep 2017.

Yaşayanlar, İsmail, "Bir Hastalık Olarak Kolera ve Tarihte Kolera Pandemileri” Toplumsal Tarih Dergisi, S. 296, İstanbul 2018, s.49-55.

Yıldırım, Nuran, “1893'te İstanbul'da Kolera Salgını”, Tarih ve Toplum Ansiklopedik Dergi, S. 129, İstanbul 1994, s.14-25.

Yıldırım, Nuran, “1893 İstanbul Kolera Salgını İstatistikleri”, Tarih ve Toplum Dergisi, S. 150, İstanbul 1996, s.51-54.

Yıldırım, Nuran, “Tersane-i Âmire Fabrikalarında Tebhir Makinesi/Etüv Üretimi ve Kullanımı”, Dünü ve Bugünü ile Haliç Sempozyumu Bildirileri, 22-23 Mayıs 2003. Ed. S.F.Göncüoğlu, Kadir Has Üniversitesi Yay. İstanbul 2004, s. 421-431.

Yıldırım, Nuran, “Su İle Gelen Ölüm: Kolera ve İstanbul Suları", Toplumsal Tarih Dergisi, S. 145, İstanbul 2006, s. 1-11.

Yıldırım, Nuran, "Osmanlı Coğrafyasında Karantina Uygulamalarına İsyanlar: Karantina İstemezük", Toplumsal Tarih, İstanbul 2006, S. 150, s.18-27.

Yıldırım, Nuran, "Kolera Salgınlarında Şehir Hijyeni: İstanbul'da Kanalizasyonlar, Su Şebekesi ve Tedbirhaneler", Mimarlık ve Tasarım Kültürü Dergisi, S. 342, İstanbul 2020, s.87-95.

Yıldız, Fatma, 19. Yüzyıl'da Anadolu'da Salgın Hastalıklar ( Veba, Kolera, Çiçek, Sitma) ve Salgın Hastalıklarla Mücadele Yöntemleri, Basılmamış Yüksek Lisans Tezi, Denizli 2014.

Yılmaz, Özgür, "1847-1848 Kolera Salgını ve Osmanlı Coğrafyasındaki Etkileri”, Avrasya Incelemeleri Dergisi, VI/1, 2017, s. 23-55.

Yolalıcı, M. Emin, "Osmanlılarda Çağdaş Belediyecilik”, Türkler Serisi, Editör: Hasan Celal Güzel- Salim Koca, Yeni Türkiye Yayınları, Cilt 13, Ankara 2002, s.1336-1356. 